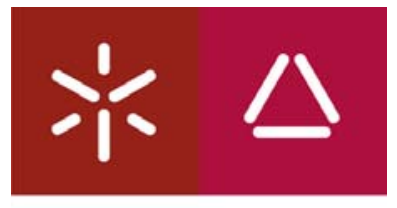

Universidade do Minho

Instituto de Ciências Sociais
Centro de Estudos de Comunicação e Sociedade http://www.cecs.uminho.pt

\title{
Telecommunications Reforms in Portugal and the European Union*
}

\author{
Helena Sousa \\ Professora Associada \\ helena@ics.uminho.pt
}

Universidade do Minho

Centro de Estudos de Comunicação e Sociedade

Campus de Gualtar

4710-057 Braga

Portugal

*SOUSA, H. (1996) "Telecommunications Reforms in Portugal and the European Union" in

Telecommunications Policy, Vol.20, no9, PERGAMON 


\begin{abstract}
The social democrats, in office from 1985 to 1995, have introduced significant reforms in the Portuguese telecommunications sector. The terminal equipment and advanced services were liberalised; the separation of the regulatory and operational functions became effective; the telecommunications sector underwent a major re-restructuring which involved the merger of the three main public telecommunications operators and, finally, the main operator, Portugal Telecom, was partly privatised. The EU has certainly played a part in the national telecommunications reform but this article argues that, although most of the policy decisions adopted in Portugal are in accordance with the EU policy framework, it does not necessarily follow that they were imposed by the Union and that they were in contradiction with the government's short-time objectives.
\end{abstract}

\title{
Telecommunications Reforms in Portugal and the European Union
}

The social democrats, in office from 1985 to 1995, have introduced significant reforms in the Portuguese telecommunications sector. The terminal equipment and advanced services were liberalised; the separation of the regulatory and operational functions became effective; the telecommunications sector underwent a major re-restructuring which involved the merger of the three main public telecommunications operators and, finally, the main operator, Portugal Telecom, was partly privatised. The EU has certainly played a part in the national telecommunications reform but this article argues that, although most of the policy decisions adopted in Portugal are in accordance with the EU policy framework, it does not necessarily follow that they were imposed by the Union and that they were in contradiction with the government's short-time objectives.

When Portugal joined the EC in 1986, the Community was still struggling for legitimacy to intervene in the most controversial areas of telecommunications policy. From the creation of the Task Force on Information Technology within DGIII in 1983 up until the publication of the 1987 Green Paper, the Task Force had to work extremely 
hard to develop a coalition of supporters for its future action and to co-ordinate different initiatives within the Commission by DGXIII, DGIII, DGIV and DGXII. Despite the lack of movement in the opening of markets, in November 1984, the Commission managed to gain agreement from the Council to its five-pronged policy proposals designed to i) create a community market for telecommunications equipment and terminals via standardisation, mutual recognition of type approvals and the opening of access to public contracts; ii) improve the development of ISDN; iii) launch a development programme of advanced telecommunications services and networks, and implement infrastructure projects of common interest (RACE); iv) promote the development of advanced services for less favoured regions (STAR) and v) co-ordinate negotiating positions with regard to international bodies ${ }^{1}$.

Although the Community was short in binding legislation until the publication of the 1987 Green Paper, several relevant Council documents were approved along the lines of the five-pronged policy proposals mentioned above. Indeed, the actual EC intervention in the telecommunications sector - when Portugal joined - revolved around industrial policy initiatives and R\&D programmes. Programmes such as ESPRIT and RACE were showing some results and the development of ISDN was perceived as crucial to the competitiveness of the European industry. Wider liberalisation was already on the agenda but, because consensus was difficult, not much progress was made until the Green Paper was published.

\section{The EU's Legal Framework}

When Portugal became an EC-member state, there was no legal obligation to introduce any change in the structure of the Portuguese telecommunications, but the national authorities felt under pressure to modernise and to open up the telecommunications sector. On the one hand, they wanted to be seen as 'true Europeans'

\footnotetext{
${ }^{1}$ Hills, J, and Papathanassopoulos The Democracy Gap Greenwood, London (1991)
} 
and, on the other hand, what they understood as the most successful countries (the US, UK and Japan) had already introduced changes in their telecommunications markets ${ }^{2}$. In fact, these countries, then run by conservative governments, had already broken-up their PTT monopolies and privatised (partly at least) their public operators.

With the development of a wider Common Market in perspective (the Single European Act was signed in 1986), the Commission argued for a common market in telecommunications terminal equipment, a common market in telecommunications services, and a common market in network equipment, supposedly to ensure the Community's future position in large-scale information technology ${ }^{3}$. The liberalisation of equipment and services would also require the separation of regulators and operators. The provisions of the network infrastructure and basic services were to remain unchallenged, under the control of national PTTs.

Being a consultation document, the Green Paper required subsequent legislation to implement its provisions. During the process of drafting legislation some compromises became unavoidable, weakening somewhat the original positions ${ }^{4}$. A number of directives, decisions and recommendations followed. Amongst the most relevant binding legislation are the 1988 directive on competition in terminal equipment markets $^{5}$ and the 1990 directive on competition in the telecommunications services markets $^{6}$. The former prevents member states from granting special or exclusive rights to a private or public body for the importation, connection or bringing into service of terminal equipment; the latter says that member states shall withdraw special or

\footnotetext{
${ }^{2}$ The liberalisation drift started in the US in the 1960's culminating with the divestiture of AT\&T in 1984. In the same year, the British telecommunications operator, BT, was privatised and a duopoly network structure was set up. Correspondingly, in Japan, in the very same year, the long distance network was liberalised and the telecommunications operator, NTT, was partially privatised.

${ }^{3}$ Commission of the European Communities Green Paper on the Development of the Common Market for Telecommunications Services and Equipment (COM (87) 290 final) 30 June 1987, Brussels, CEC

${ }^{4}$ Bauer, Johannes, and Charles Steinfield 'Telecommunications Initiatives of the European Communities' in Steinfield, Charles et al (eds) Telecommunications in Transition Sage, Thousand Oaks (1994)

${ }^{5}$ Commission of the European Communities Commission Directive of 16 May 1988 on Competition in the Markets in Telecommunications Terminal Equipment (88/301/EEC; OJ L131/73, 27.05.88)

${ }^{6}$ Council of the European Communities Council Directive of 28 June 1990 on Competition in the Markets for Telecommunications Services (90/388/EEC; OJ L192/10, 24.07.90)
} 
exclusive rights for the supply of telecommunications services other than voice telephony and shall take the necessary measures to ensure that any operator is entitled to supply such telecommunications services.

The EU has been mainly preoccupied with equipment market liberalisation and value-added services such as satellite and mobile communications but, since 1994, its activity has intensified around infrastructure liberalisation. The Bangemann Report ${ }^{7}$ subscribed to by Portugal - argues that infrastructure competition is a crucial stage in the development of the EU telecommunications policy. Furthermore, the EU is pushing for the introduction of competition in voice telephony. Although the Commission's plans to introduce it as soon as 1996 were abandoned, most EU member states have now agreed that they would liberalise basic voice services by 1998, being Portugal and Greece the exception. Portugal has announced plans to liberalise in 2000 and Greece will probably liberalise in 2003.

Though Portugal was one of the countries which asked for an extension in the liberalisation of voice telephony, so far its regulatory reforms have been well in line with the EU telecommunications policy framework. But, as senior EU officials recognise, the advantages of competition for advanced countries are easier to demonstrate: 'there are industrial interests to support, they have a strong local market and the associated economies of scale - and they can use these as a springboard for expansion into other markets'8. Concentration of manufacturing supply across national borders has resulted in Siemens of Germany and Alcatel of France becoming the major European manufacturers. With the extension of EU membership, these have now been joined by Ericsson of Sweden. World oversupply of equipment, coupled with the convergence of computing and telecommunications, and the penetration of the

\footnotetext{
${ }^{7}$ Bangemann et al (members of the High-level Group on the Information Society) Europe and the Global Information Society: Recommendations to the European Council Brussels (26 may 1994)

${ }^{8}$ Berben, Cor, and Clements B 'The European framework for competition in telecommunications, the benefits for peripheral countries' Telecommunications Policy 199519 (4) pp 276
} 
telecommunications sector by computer companies, have resulted in fierce competition for exports and the politicisation of such exports ${ }^{9}$.

Indeed, it is relatively easy to assess the benefits of EU's telecommunications policy for more industrialised countries, but it all becomes rather more complicated if one attempts to value the benefits for less favoured regions such as Portugal. Indeed, the Commission has put forward little more than general hypotheses. The benefits for LFRs are likely to be based on the 'macroeconomic impact of improved services, the encouragement of inward investment in the sector, and the participation of strong and efficient local operators in global ventures'. No serious attempt has been made by governments and/or by the EU to provide empirical evidence to sustain their claims about the benefits of the new regulatory framework for LFRs.

\section{The EU's R\&D Programmes}

It has not been the EU liberal policies but the EU dirigiste policies which have directly benefited - even if in limited terms - the Portuguese under-developed telecommunications sector. There are conflicting views within the Commission and, as a result, contradictory policies have been developed. A more liberal sector argued for more liberalisation whilst a more dirigiste one argued for further intervention mainly through R\&D programmes. The ESPRIT and RACE programmes are the most visible face of the EU interventionist industrial policy but they had not been conceived to address the special needs of LFRs. The STAR programme and the subsequent Telematique programme are the sole relevant example of the trade-off between the Commission and LFRs for opening up their telecommunications market.

\footnotetext{
${ }^{9}$ Michalis, Maria, and Hills, Jill A New Regulatory Régime for European Telecommunications paper presented to the University Association for Contemporary European Studies 'After the Single Market: Services Regulation, Trade and Employment' London 3 March 1995
} 
A general report to the Commission on the impact of the $E U R \& D$ programmes in Portugal from 1986 to $1991^{10}$, pointed out that the most relevant Portuguese participation was through programmes having a direct link to economic matters. $50 \%$ of the participation is in the area of IT and industrial modernisation. In fact, only two programmes, amongst 37, had a Portuguese involvement of over 30 contracts (BRITE-EURAM and ESPRIT). The Lisbon region accounted for more than $72 \%$ of the national participation in EU R\&D programmes. In addition to reinforcing the existing centralising trends, the EU R\&D programmes are not believed to play any leading role. In nearly $80 \%$ of the cases European programmes are felt as reinforcing the normal activities of participating teams, especially in the fields of IT and telecommunications, exploitation of biological resources and exploitation of marine resources $^{11}$. The financial impact of European R\&D programmes in the relevant period was globally small (around 5\% of gross expenditure in $\mathrm{R} \& \mathrm{D}$ ) but locally very significant (around $40 \%$ of the research budget of participating teams) ${ }^{12}$.

Accounting for only $5 \%$ of the gross expenditure in $R \& D$, it cannot be assumed that EU programmes are making any structural difference in the research pattern of this member-state. As we are particularly concerned with telecommunications, we will now contemplate the EU programmes dealing specifically with this sector. ESPRIT, one of the most significant R\&D programmes ${ }^{13}$, supports research projects in the fields of microelectronics, information processing systems and software, and as such it cannot be properly considered a telecommunications programme. So, it can be said that RACE is the only EU costly programme which dealt specifically with telecommunications. The objective of RACE was to generate R\&D cooperation among manufacturers, PTOs, and research institutions within Europe, and by doing so, to stimulate innovation and competitiveness in the European industry. The

\footnotetext{
${ }^{10}$ Caraça, J M G et al Study of the Impact of Community RTD Programmes on the Portuguese S\&T Potential Junta Nacional de Investigação Científica e Tecnológica, Lisbon (1993) pp 15-24

${ }^{11}$ Ibid pp 33

${ }^{12}$ Ibid pp 53

${ }^{13}$ The budget of the ESPRIT programme from 1987 to 1991 was 1,600 million ECU and from 1990 to 1994 was 1,339 .
} 
ultimate goal of these efforts was the introduction of Integrated Broadband Communications (IBC) by $1995^{14}$. The programme's budget was of 550 million ECU for the period between 1987 to 1991 and 484 million ECU for the period between 1990 to 199415 .

Just like ESPRIT, the RACE programme had not been designed to address the needs of the LFRs in general nor the needs of Portugal in particular. In the 1980's these countries were still struggling with network expansion and with very low penetration rates. In Portugal, for example, in the late 1980's the penetration rate was about half of the European average. Hence, the introduction of broadband communications could not have been a priority. As shown in table 1 and table 2, only the core countries and the big manufacturers and PTOs have taken full advantage of the RACE programme.

\section{TABLE 1}

\section{TABLE 2}

In fact, from the analysis of these tables, it is crystal-clear that the three largest EU countries (UK, Germany and France) are those which have benefited the most in terms of numbers of participations and in terms of project leadership. Even non-member states (Sweden, Finland and Austria joined the EU in January 1995) benefited more (Sweden) or almost as much as Portugal (Finland and Norway). Furthermore, there is no single Portuguese company among the 21 most involved in R\&D projects.

\footnotetext{
${ }^{14}$ See e.g. Ungerer, Herbert, and Costello Telecommunications in Europe EC official publications, Luxembourg (1990)

${ }^{15}$ Schnöring, Thomas 'European Telecommunications R\&D Systems in Transition' in Steinfield, Charles et al (eds) Telecommunications in Transition Sage, Thousand Oaks (1994) 
The Commission is not necessarily the true policy initiator and much of the EU actual policy often reflects competing national interests. In fact, the EU's most influential countries (Germany, France and the UK) have never been too concerned with the development of specific programmes for LFRs. LFRs themselves have not had the necessary weight to properly counterbalance the interests of core countries. Council negotiations - often behind closed doors - are therefore strenuous, and decisions are reached through various trade-offs, the so-called package deals.

In these circumstances, it comes as no surprise that from the 1987 Green Paper to the CEC's 1992 Review on Telecommunications services ${ }^{16}$, there have been few mentions of the specific concerns of less developed and peripheral regions. 'Where they have appeared, they have been dealt with summarily and in little depth'17. In any case, some trade-offs were inevitable and STAR and later Telematique programmes were launched. STAR was approved in the October 1986 Council and was implemented from 1987 to 1991 with EU financial aid of 780 million ECU (the EU contribution varied from $50 \%$ to $100 \%$, according to type of project). The STAR's successor Telematique programme had a much smaller EU contribution - around 200 million ECU18. STAR and Telematique were Community Programmes run jointly by DGXIII and DGXVI, and in contrast to the research programmes, were financed by the European Regional Development Fund (ERDF).

During the five-year period of STAR, it contributed approximately $2 \%$ of the total investment of the Telecommunications Operators (TOs) in the LFRs or the equivalent of what TOs are investing every two months. Since peripheral regions as a whole lag behind core regions by 10 years, by this yardstick a further 60 STAR programmes would be required to catch up (all other things being equal) ${ }^{19}$. In any case,

\footnotetext{
${ }^{16}$ Commission of the European Communities 1992 Review of the Situation in the Telecommunications Services Sector (Sec (92) 1048 final ) Brussels, (10 July 1992)

${ }^{17}$ O Siochrú, Séan The EC's Telecommunications Policy and Less Favoured Regions: the Role of the STAR Programme paper delivered at the IAMCR Conference, Dublin (24-26 June 1993)

${ }^{18}$ Ibid

${ }^{19}$ Ibid 
according to O Siochrú, even the most conservative estimates demonstrate the inadequacy of STAR to the task that telecommunications policy demanded of it ${ }^{20}$.

Through the STAR programme, Portugal received EU financial assistance of around 120 million ECU ${ }^{21}$ which, considering for instance overall budgets of ESPRIT and RACE, is a very restrained amount. The financial limitations of the STAR programme for Portugal are recognised by the STAR National Commission which stated in the final report on the STAR programme that 'much more would have been done, had the EU contribution been higher'22. This recognition is quite significant since the STAR Commission produced a hyped analysis of the benefits of the STAR programme, considering it 'crucial to the creation of infrastructures needed to the introduction of advanced services'23. In fact, of the 2,234 short-listed national applications to the STAR programme, only 1,318 could be partly financed ${ }^{24}$.

Although the STAR programme was clearly insufficient to deal with the specific needs of this LFR, it did have a positive impact on the expansion of the infrastructure and in the long overdue introduction of advanced services. Given that more than a thousand projects got financial support, the STAR programme has unequivocally speeded up the introduction of services such as mobile phone, videotex and videoconference. Table 3 presents the type and number of projects financed by STAR.

\section{TABLE 3}

\footnotetext{
${ }^{20}$ Ibid

${ }^{21}$ Comissão Nacional do Programa STAR Portugal, Programa STAR, Relatório Final de Execução Comissão Nacional do Programa STAR, Lisbon (April 1993)

${ }^{22}$ Ibid

${ }^{23}$ Ibid

${ }^{24}$ Ibid 
Following STAR, another programme for telecommunications in LFRs was approved. The Telematique programme started being implemented in Portugal in 1992 and is run by the National Commission for the STAR programme. According to the commission, the objective of this programme - subsequent to STAR - is to develop advanced services, creating a national dynamic which would continue to favour the access and systematic usage of these services ${ }^{25}$. In practice, Telematique is no more than extra financing for the task initiated by STAR. The maximum amount from EU structural funds for this programme was around 34 million ECU ${ }^{26}$. The Telematique programme was still under way when the empirical research for this article was undertaken, so no final evaluation existed. In any case, the meagre amount of financial resources allocated to the programme suggests that it would not add substantially to what had already been done under STAR.

Though recognising the inadequate nature of STAR and Telematique to implement the EU policy of economic and technological convergence, it is indisputable that in LFRs these programmes have created a great interest in advanced services provision. Indeed, as O Siochrú puts it, STAR funds created a class of advanced services entrepreneurs, actively seeking opportunities to develop services. It is even possible that at the present time there is more activity on the ground in the LFRs in these technologies than in core regions ${ }^{27}$. In Portugal, an indication of this interest is given by the number of projects submitted to these programmes. STAR and Telematique helped create the momentum for the introduction and development of advanced services.

\section{National Telecommunications Policies}

\footnotetext{
${ }^{25}$ Comissão Nacional do Programa STAR Portugal,, Relatório Final de Execução do Programa Operacional Telematique Comissão Nacional do Programa STAR, Lisbon (March 1993)

${ }^{26}$ Ibid

${ }^{27}$ O Siochrú, Séan, op cit
} 
When we refer to nationally-based policies, we do not mean that domestic policies are taken in isolation from the regional scene. Our meaning is that, although operating within the EU regulatory framework, Portugal still has room for manoeuvre in the decision-making process and in the implementation of policies. The EU framework is quite generalist and most of the recent telecommunications policies taken in Portugal cannot be explained by the regional setting. Even when national authorities are persuaded by the Commission's arguments and/or by the Council's package deals to move in a given direction - if no binding legislation already exists - the final responsibility for their actions falls on national government's hands. Yet, the separation between regional and national policies is still pressing because it was the government's own expressed policy to, first and foremost, defend the national interest and to maintain telecommunications in national hands 28.

The current telecommunications policy results partly from external sources (although it was ultimately Portugal which has conceded elements of its national sovereignty to the EU) and partly from a combination of nationally-based options. When Portugal joined the EC, the need to modernise and re-organise the telecommunications sector had already been recognised but the accession has intensified the pressure for change. On May 1986 - four months after the accession Sequeira Braga, head of Secretaria de Estado dos Transportes e Comunicações (SETC) requested a study to examine Portuguese telecommunications and to report on the most pressing issues in this area. One year later, the Comissão para o Estudo do Desenvolvimento Institucional e Tecnológico das Comunicações (CEDITC) presented the study to the Ministério of Public Works, Transport and Communications.

In line with what was being discussed in the EC at the time, this study recommended the following sectorial changes: i) the regulatory body Instituto das Comunicações de Portugal (ICP) should initiate its activities; ii) a holding company

\footnotetext{
${ }^{28}$ See e.g. speeches delivered by the telecommunications ministro (secretary of state), Ferreira do Amaral, at the 4th and 5th APDC congresses in Lisbon. These speeches were published in Comunicações (January/February 1993) and Comunicações (January/February 1995), respectively.
} 
should be set up to increase the efficiency of public operators; iii) postal and telecommunications services should be separated; iv) measures should be taken to prepare the opening up of telecommunications operators to private capital; v) more flexibility should be introduced in new telecommunications services; vi) prices should be liberalised in the non-basic telecommunications sub-sector ${ }^{29}$. These recommendations were largely adopted by the 11th Constitutional Government (19871991) and constituted an important input to the 1989 Basic Telecommunications Law ${ }^{30}$.

\section{Opening up the Market to Competition}

Amongst the CEDITC recommendations, the first to be implemented was the separation of the regulatory and operational functions. The ICP gained effective legal existence through the law decree 283/89 of 23 August 198931. This piece of legislation supposedly created an environment which would allow an even-handed introduction of competition in telecommunications services. The EU and indeed other pro-competition international actors had been arguing that the dual regulatory and commercial function of the telecommunications operator could not be sustained in a new competitive environment because of the conflict of interests. Although these arguments were accepted and ICP was set up before the directive on competition in the markets for telecommunications services ${ }^{32}$, no real autonomy was granted by the Portuguese government to the regulatory institute.

According to the law decree 283/89, ICP has a vast array of responsibilities to perform, namely to actively contribute to the sector's legal framework; to provide assistance to the government for the purposes of carrying out its tutelage

\footnotetext{
${ }^{29}$ Ministério das Obras Públicas, Transportes e Comunicações Desenvolvimento Institucional $e$ Tecnológico das Comunicações MOPTC, Lisbon (1987)

${ }^{30} \mathrm{Law}$ n$^{\circ} 88 / 89$ of 11 September

${ }^{31}$ The ICP was formally created in 1981 under the law decree 181/81 of 2nd of July but this legislation has not produced any results until the 1989 go ahead.

${ }^{32}$ In addition to the opening up of the telecommunications services, this directive (90/388/EEC of 28 June 1990) also contemplates the separation of regulatory and commercial functions.
} 
responsibilities; to co-ordinate, on a national level, all matters concerning the carrying out of treaties, conventions and international agreements; to approve materials and equipment, to undertake the management of the radio electric spectrum; to license public sector communications operators in addition to providers of value added services; among others. The difficulty however is that, with the exception of technical matters, the ICP has merely an advisory/supportive role. No line has been clearly drawn between what is a policy and a regulatory issue. Furthermore, the members of the board of directors are appointed by a resolution of the Council of Ministers. So, even with its legally recognised administrative and financial autonomy ${ }^{33}$ and despite feasible strains, the ICP cannot be said to be a truly independent body.

Immediately after the legal setting up of ICP, the Basic Law on the establishment, management and exploitation of telecommunications infrastructures and services (88/89 of 11 September 1989) was approved by the National Assembly. This Telecommunications Act can be understood as a real watershed in the Portuguese telecommunications legal history because, for the first time, the general principles for the sector were compiled in the same piece of legislation. According to this law, it is the responsibility of the state to guarantee the existence and availability of fundamental services, including fixed telephone services, telex and a switched data transmission service. However, the exploitation of services involving the use of complementary telecommunications infrastructures may be carried out by public and private companies, once properly licensed.

Similarly, the provision of value added services may be made by any singular person or collective body (under specific conditions) and by the public telecommunications carriers and complementary telecommunications companies. To sum up, apart from the fundamental services, which would continue to be provided by the state, other actors - either private or public - could from then on apply to become

33 The ICP has to generate its own financial resources which is achieved mainly from the spectrum management (spectrum users pay ICP directly) and from the issuing of licenses. 
services providers. Only the telecommunications infrastructure was to remain firmly under the responsibility of the public telecommunications carrier.

Although new entrants would have to comply with specific rules and regulations, the Telecommunications Act sets out some requirements concerning protection of competition. It states that public telecommunications carriers should guarantee the use of their networks for all communications carriers under equal competitive conditions. When public carriers provide complementary services they are equally forbidden to use any practice which may distort conditions of competitiveness or which are considered to be an abuse of a leading position. These legal provisions have not prevented alleged abuses of dominant position and accusations of unfair competition have been frequently reported.

These legal instruments - notwithstanding their significance - were not particularly controversial as the changes were perceived both as necessary and inevitable by both the government and the opposition main party, the Socialist Party. In general terms, it can be argued that the creation of ICP and the liberalisation of valueadded services were directly and indirectly related to the EU legal framework. If Portugal had not passed this legislation, it would have had to comply later on with the ONP Council directive ${ }^{34}$, with the Services directive ${ }^{35}$ and subsequent legislation.

Even if these changes were ultimately introduced by the national parliament and/or government, it is quite clear that the EU played a role here. For ideological, political and economic reasons, the EU persuasively convinced the member states that no alternative existed but to open up their markets. Core countries had very concrete interests in doing so whilst peripheral countries were convinced that they had not much to lose. So, the Council ended up approving legislation that would make it more difficult for member-states to take protectionist measures.

\footnotetext{
${ }^{34}$ Council of the European Communities Council Directive of 28 June 1990 on the Establishment of the Internal Market for Telecommunications Services through the Implementation of Open Network Provision (90/387/EEC; OJ L 192/1, 24.07.90)

${ }^{35}$ Council of the European Communities, 90/388/EEC, op cit
} 


\section{The Re-organisation of the Sector}

In addition to the opening up of the telecommunications market to new entrants, the Portuguese authorities believed that the three traditional public operators (Correios e Telecomunicações de Portugal, CTT; Telefones de Lisboa e Porto, TLP and Marconi ${ }^{36}$ ) had to go through a re-organisation process. These operators were - for historical reasons - organised on a geographical basis ${ }^{37}$ which was considered by the government as inappropriate. So, a financial holding society, Comunicações Nacionais (CN) was set up on $1992^{38}$ mainly to co-ordinate the sector, to define investment/business strategies and to deal with the privatisation process. CN started its operations in early 1993 comprising five independent public companies: the former postal services of CTT, now an independent company (also called CTT), Telecom Portugal (TP), the telecommunications arm of the earlier CTT, Teledifusora de Portugal (TDP) ${ }^{39}$, TLP and Marconi.

The creation of CN was defended by its chairperson, Cabral da Fonseca, as being the 'rational' choice for the sector. The two other alternatives were to maintain the historical scenario or to merge the companies, but the holding company was - according to him - the only solution with small disadvantages ${ }^{40}$. This view, however, would not be maintained for long as Telecom Portugal would soon put in place its strategy to become the dominant actor in the Portuguese telecommunications scene. The president of Telecom Portugal from 1990 to 1992, Gonçalo Areia, had already publicly argued for the setting up of a single telecommunications operator ${ }^{41}$. But it would be the next

\footnotetext{
${ }^{36}$ Marconi was considered a public operator but $49 \%$ of its shares were in private hands.

${ }^{37}$ CTT used to supply local telephony to the entire country with the exception of the two main cities, Lisbon and Oporto, and long distance communications to Europe and North Africa; TLP used to cover Lisbon and Oporto while Marconi had the monopoly of cable and satellite communications to the rest of the world

${ }^{38}$ Law decree 88/92 of 14 April 1992

${ }^{39}$ TDP was set up through law decree 138/91 of 8 April 1991 in order to distribute broadcasting signals for RTP and for the forthcoming television companies.

${ }^{40}$ See Público, 9 December 1992

${ }^{41}$ Expresso, 19 December 1992: Economia
} 
president, Luís Todo Bom, (also vice-president of the Social Democrat Party) who would convince $\mathrm{CN}$ and the social democrat government that the company he chaired was the only one that could adequately lead the re-organisation process. The plan was to take over TDP, TLP and Marconi.

Fierce resistance towards what was then called the TP's 'secret plan', soon broke out. The Marconi's president, Sequeira Braga, and the TLP's president, Mello Franco, strongly opposed the idea as they wanted the identity of their companies preserved. Amongst other criticisms, these two operators argued 1) that the reorganisation process would be very expensive, 2) that a mega-company would be too expensive for national investors in the forthcoming privatisation, 3) that Marconi already has private capital which would complicate even further the process, 4) that lay offs would be inevitable if a merger occurred and 5) that each company had its own organisational culture ${ }^{42}$.

Marconi was, by far, the company which tried hardest to avoid the take over. In addition to intense lobbying, the company tried to position itself in such a way that would make it very difficult for it to be absorbed by PT. Marconi expanded into new markets and services and strengthened its position into the international communications market. A strategic alliance (Atlantic Alliance) was established with the Brazilian long distance telecommunications operator, Embratel, to provide global telecommunications services and to promote joint investment abroad. The company's position in the Chinese market was also built up with the signing of a co-operation and development agreement in the field of telecommunications with the Chinese authorities. At the same time, a satellite communications company was set up in Macau, in association with local companies from Macau and the People's Republic of China. Also, in 1994, the company was awarded several paging contracts in the Indian market and

\footnotetext{
${ }^{42}$ Expresso, 23 October 1993:C2
} 
acquired a stake in a satellite communications company in Hungary ${ }^{43}$. Marconi was then operating in more than 15 countries, solidifying its image both externally and internally.

The predecessor of the ministro Ferreira do Amaral, Oliveira Martins, also argued against the TP's/government merger strategy, considering it 'absurd'. Whilst in other public service companies, the government talks about liberalisation of monopolies, in the telecommunications sector, the governments wants to 'integrate everything in a monster which will have more than 20,000 employees and where everything will be mixed up'44. In 1987, when Oliveira Martins was ministro and Sequeira Braga was secretário de estado, the government's strategy was to preserve the companies' identity and to grant administrative autonomy to CTT and TLP. In fact, 'the big the better' strategy was severely criticised and strongly opposed but Luís Todo Bom had already convinced the ministro Ferreira do Amaral and his close ally, Cabral da Fonseca, chairperson of $\mathrm{CN}$, that concentration was the best solution for the Portuguese telecommunications sector.

So, despite Marconi's full thrust strategy and fierce criticisms from the government's own ranks, the merger went ahead. On the 20th of November 1993, in a long interview to Expresso newspaper, Cabral da Fonseca, argued that more than one company providing basic services in a country with ten million inhabitants and with the Portuguese GDP was unthinkable: 'there is no way of surviving in a competitive environment'. The CN's president previously believed that Portugal should have two basic service operators, one international (possibly the historic Marconi) and one national (possibly a new company resulting from the merger between TP and TLP) ${ }^{45}$. No clear case was put forward to defend his new point of view but it became quite clear whose lobbying was more efficient. Interestingly enough, Luís Todo Bom has also never put forward a clear set of arguments to justify publicly why - in a country which has traditionally had three operators - a single PTT would provide a better service. He

\footnotetext{
${ }^{43}$ Marconi Annual Report 1993 Marconi Global Communications, Lisbon (1994)

${ }^{44}$ Quoted in Expresso, 19 March 1994; see also interview to O Independente, 9 December 1994

${ }^{45}$ See Público, 10 September 1993 and Público 30 October 1993
} 
has argued, in very general terms, that Portugal should follow the Dutch model which is based on a single PTT and, furthermore, that the creation of a single telecommunications operation was essential to fight foreign competition when the market is fully liberalised between 1998 and $2003^{46}$.

In early 1994, this most controversial issue was settled, and contrary to previous decisions, the first phase of the merger operation did occur. A new company, Portugal Telecom (PT) was finally set $\mathrm{up}^{47}$. PT resulted from the merger of TP, TLP and TDP. The financial holding company, CN, would go on supervising the new PT, Marconi and CTT. CTT's postal services were never meant to be part of PT but Marconi would not remain independent for long. However, the incorporation of Marconi brought up more complex issues. Whilst TLP and TDP had a relatively small dimension, $100 \%$ of their capital was public and no international links had been established, Marconi had $49 \%$ of its capital in private hands, had well established international links and alliances and its concession contract would only be over by 2001 .

Marconi's integration had already been decided but it was only in April 1995 that CN transferred 51\% of Marconi's state owned shares to Portugal Telecom. PT became then Marconi's biggest shareholder and, once it controlled the company, it was not hard to get Marconi's small shareholders to exchange their shares for PT ones. The exchange of shares was done during the first stage of PT's privatisation, in May 1995, when PT managed to gain control over more than $90 \%$ of Marconi's capital ${ }^{48}$. With Marconi's actual integration, Portugal had for the first time what European countries used to have in the past: all basic telecommunications services under the umbrella of a single operator.

Neither the government nor the operator which has benefited the most from the re-organisation (PT) have been able to justify the paradox of arguing simultaneously

\footnotetext{
46Público, 10 September 1993

${ }^{47}$ Law decree 122/94 of 14 May 1994

${ }^{48}$ Diário de Notícias, 30 May 1995
} 
for liberalisation and for concentration. On the one hand, it has been argued that liberalisation and full competition can only benefit the consumer; on the other hand, it has been argued that only a big operator can respond to the challenges imposed by liberalisation. In any case, because the re-organisation process was designed behind closed doors with no public debate and adequate consideration for long standing actors in the field, there was no need to prepare a consistent case. The process was conducted with speed but it certainly lacked participation.

\section{The Privatisation of Portugal Telecom}

Just as with the re-organisation of the sector, the partial privatisation of Portugal Telecom is not a direct result of EU policies. According to O Siochrú, the only acknowledged problem the EU has expressed about LFRs concerned where they would find the resources to 'keep pace' with liberalisation - 'and indeed this may be no more than a veiled reference to privatisation'49. But, even if the EU has tried to convince its members to privatise, it has no open policy on the issue and member states can decide their own strategies. Portugal has decided to follow the North American/European bandwagon.

The ministro Ferreira do Amaral has publicly stated that - whether we want it or not - the telecommunications sector will be exclusively private because public companies have no agility nor vocation to stand a chance in a competitive market. 'This is happening in all countries in the world. I do not know any [country] which is, at this stage, thinking about nationalising the telecommunications sector and the vast majority is thinking about privatising'50. From this speech, two features emerge: i) if most countries are privatising, Portugal must do it as well, ii) even if Portugal resists privatisation, it would happen anyway. Yet, Ferreira do Amaral has not attempted to

\footnotetext{
${ }^{49}$ O Siochrú (1993) op cit

${ }^{50}$ Speech delivered at the APDC conference in Lisbon, November 1994
} 
explain the benefits of privatisation and he has not attempted to explain why public companies (whose managers have been appointed by the social democrats over the last decade) have performed poorly. The telecommunications sector in the country was in private hands since the 19th century up until the 1960's, and in the public sector ever since. In both periods it has performed deficiently. The arguments for less state intervention in the economy and the subsequent privatisation of PT were legitimised on an ideological basis as no evidence of its benefits is provided.

Apart from these general considerations about the benefits of privatisation, the government had indeed very concrete reasons to push for it. Both CTT and PT had huge financial deficits in their pensions funds because part of these resources had been used to invest in the sector. The combined deficit of CTT and PT funds was estimated by Cabral da Fonseca between $£ 560$ million and £1,120 million ${ }^{51}$. Commissioned by CN, the British company, Bacon \& Woodrow, calculated that - although part of the removed money had already been paid back - there was still $£ 800$ million missing52. The privatisation of PT was certainly an easy way of replacing the money which should not have been so readily removed from the pension funds in the first place. Furthermore, the ministério of Finances was urging privatisation in the expectation that it could generate extra funds. In a pre-electoral period, raising taxes was unthinkable but the government had to cope with increasing national demands and with the requirement of co-financing EU projects for the country.

The timing for privatisation was not accidental either. The government wanted to initiate privatisation before other continental operators (e.g. Telecom Italia, Telefonica, Deutsche Telekom, France Telecom, etc.). There was an understanding that if it was not done before their privatisation, their would be insufficient demand and Portugal would have serious difficulties in selling PT shares. Additionally, it had to be done before the legislative elections of October 1995 because, in this legislature, no

\footnotetext{
${ }^{51}$ Expresso, 19 April 1994

52Expresso, 14 May 1994; see also Público, 15 August 1994
} 
robust opposition to privatisation existed and also because, when the government presented its telecommunications achievements to the electorate, the privatisation start up would seemingly 'complete' previous reforms.

On the 20th of March 1995, just before the privatisation went ahead, the government granted PT a public service concession contract for 30 years (due for renewal in 15 years). According to this contract ${ }^{53}$, PT has the exclusive right to provide basic telecommunications services and to manage all telecommunications infrastructures which support these services. So, when the company was put on the market, it had a solid contract granting it the monopoly of most telecommunications services in the country. But the public service contract had little impact and it has not diminished criticism about the way the process was conducted. The government was particularly criticised because of PT's privatisation timing and valuation. Several Portuguese actors involved in the telecommunications sector argued that privatisation should be done after - and not before - wider liberalisation was brought to the sector ${ }^{54}$. Amongst other actors, the telecommunications platform ${ }^{55}$, representing the interests of four private telecommunications companies, argued that privatisation at that particular stage served foreign interests rather than national and believed that the current policy would asphyxiate embryonic private telecommunications companies ${ }^{56}$.

The valuation of the company was especially controversial because the overall value of the company declined dramatically in a short period of time. In August 1994, the consultant firm, James Capel Europe, estimated PT's value as $£ 4,000$ million7. Luís Todo Bom, in an interview to Expresso, denied press reports that PT was being poorly evaluated and stated categorically that the company was worth between $£ 3,200$ million

\footnotetext{
${ }^{53}$ See law decree 40/95 of 15 February 1995

${ }^{54}$ Before the partial privatisation of PT, only $3 \%$ of the telecommunications market was in the private sector (see Diário de Notícias, 19 November 1994)

${ }^{55}$ In Portuguese, it is called Plataforma para a Modernização das Telecomunicações

${ }^{56}$ See e.g. Diário de Notícias, 18 November 1994; Telecomunicações, n9 January 1995

${ }^{57}$ Diário de Notícias, 6 August 1994
} 
and $£ 4,000$ million ${ }^{58}$. The ESSI group - commissioned by the government to co-ordinate the privatisation process - estimated, in early 1995, that PT's value was $40 \%$ less than that James Capel had calculated the year before. Finally, PT was put on the market at a price which would vary between 1,900 million and 2,356 million ${ }^{59}$. Whatever the specific pressures put on the Portuguese government to lower PT's value, it can be assumed that the government feared that there would not be demand for PT's shares if the price was not particularly low. As such, the demand was enormous and the operation was perceived as a success ${ }^{60}$. In any case, the government was not prepared to take risks - either stopping or postponing the operation - when the October 1995 legislative elections were just around the corner.

So, the partial privatisation went ahead with around 50 million shares on the market. PT offered 23 million shares for direct sale to Portuguese and international investors and 27 million shares at a special session of the Lisbon stock exchange on the 1st of June. The 27 million included 17 million for shareholders in Marconi, 7,5 million for PT employees, small investors and emigrants, 1,5 million for PT's bondholders and one million for other shareholders ${ }^{61}$. Demand for shares in the direct sale of PT has outstripped supply fourfold. International and national investors have submitted offers for more than 80 million shares although only 23 million were made available.

From the overall $28 \%$ of PT's capital which was put on the market, 2,7\% went to the hands of the Espírito Santo group which comprises the ESSI bank. The rest is highly dispersed amongst national and international small investors, pension funds and companies $^{62}$. The operation cashed in $£ 560$ million, from which the state kept $£ 20$ million for the Treasury. £320 million went to the CTT/PT pension funds, £19 million went to the consortium - lead by Sociedade Financeira de Corretagem, part of the ESSI

\footnotetext{
583 December 1994

${ }^{59} \mathrm{O}$ Independente, 26 May 1995

${ }^{60}$ See, inter alia, Diário de Notícias, 2 July 1995

${ }^{61}$ Comunicações Nacionais et al Prospect prepared for the Privatisation of Portugal Telecom Lisbon (1995)

62Público, 4 July 1995 
bank - which co-ordinated the privatising operation. The remaining $£ 200$ million corresponded to Marconi's shares exchanged for PT's ${ }^{63}$. More than $90 \%$ of Marconi's shares in private hands were exchanged for PT shares at a previously agreed price (£26 per share) which guaranteed the total integration of Marconi in PT.

Possibly it will be the second phase of the PT's privatisation - expected to take place in June 1996 - that will prove to be crucial to the company's future. At that particular stage, the government and PT will probably seize the opportunity to establish an international alliance that will improve PT's business opportunities in the international market. The government has dismissed the need to find a strategic partner in the second stage of privatisation when $21 \%$ to $22 \%$ of the capital will be sold 64 (according to the law, no more than $49 \%$ can be in private hands). But if powerful actors - in the international scene and within PT - have a specific interest in a given alliance, it is most likely that it will be secured.

After the first stage of PT's privatisation, on the 13th of July 1995, the Council of Ministers approved the abolition of Comunicações Nacionais. CN had been coordinating the restructuring of the sector and preparing the privatisation of PT. Still, CN had not been able to actually lead the process and was too weak to fight lobbies and balance the needs and interests of the various actors involved in national telecommunications. Ferreira do Amaral, quoted in Público newspaper, argued that CN would come to an end because it has accomplished its mission ${ }^{65}$. Furthermore, Cabral da Fonseca stated that he would calmly assist the evolution of the sector because 'the essential had already been done and it is irreversible'66.

\section{Conclusions}

\footnotetext{
${ }^{63}$ Diário de Notícias, 2 June 1995

${ }^{64}$ Expresso, 3 July 1995

6514 July 1995

66Público, 14 July 1995
} 
Over the past decade, significant telecommunications reforms were introduced in Portugal. The market was opened up: terminal equipment and advanced services were liberalised; the separation of the regulatory and operational functions became effective; postal and telecommunications services were split up; the telecommunications sector underwent a major re-restructuring which involved the merger of the three main public telecommunications operators and, finally, the partial privatisation of the main operator, Portugal Telecom, has started and will probably be finalised by 1996 .

Some of these reforms, namely the opening up of the markets, were introduced because the country had to comply or would have to comply in the near future with the EU legislation. Other aspects of the Portuguese reform relating to the re-organisation of the sector and to the privatisation of Portugal Telecom have no direct relation to the EU legal framework. The re-organisation of the sector was designed and implemented by the national government and the lobbying process was also internally-based. Likewise, the privatisation of PT has taken place for very concrete domestic reasons. Capital was urgently needed to finance major investments in network expansion and in advanced services, so pension funds from public companies were used and the partial privatisation of PT was perceived as the easiest way of paying the money back. The Treasury was also keen on the privatisation, hoping to be able to generate extra funds.

So, although most of the policy decisions adopted in Portugal are in accordance with the EU policy framework, it does not necessarily mean that i) they were imposed by the Union and ii) that they were in contradiction with the government's interests. For example, the government wanted to protect PT's interests and it has taken the necessary steps to do so. In spite of the liberalisation of value added services, PT's position in the market was strengthened. The company was the clear winner of the merger process; it has continued to be the sole provider of basic services and it has also been allowed to provide a wide range of advanced services, including cable television. 
In any case, Portugal has so far complied with the EU binding legislation and policy orientations, even if it has not fully benefited from the most relevant aspects of the EU telecommunications policy, namely the opening up of the markets and $R \& D$ subsidies. The Commission itself recognises that it is relatively easy to assess the benefits of the EU telecommunications policy for more industrialised countries, but that it all becomes rather more complicated if one attempts to evaluate the benefits for countries like Portugal. Precisely because of the recognition that the EU policy does not specifically address the needs of LFRs, the Commission put forward programmes such as STAR and Telematique expecting to persuade LFRs that they had not been forgotten. Despite the meagre resources allocated to these programmes, they had a positive impact on Portuguese telecommunications: they supported the expansion of the network and they assisted in the introduction and development of advanced services such as ISDN, mobile phone, paging and videoconference.

So, it can be argued that there is a level of interdependency between the EU and Portugal in this field. Portugal might not have benefited from the most important aspects of the EU policy but has taken advantage of STAR and Telematique programmes to boost the development of national telecommunications. From the EU point of view, the opening up of the Portuguese market was perceived as relevant not only because it meant more business for core countries' industries but also because it was necessary to foster economic and political integration in this area. This interdependent relationship could have been more equitable if Portugal had not joined the EEC so late and if the country had not been isolated for so long. In fact, Portugal lacked experience in the international fora and was clearly ill-prepared to effectively negotiate for further concessions out of Europe in this particular field. Portugal has, for example, agreed to open up its telecommunications markets before the EU directives were adopted which put the country in a weak negotiating position. Had national political and technical elites had superior bargaining skills, a more even-handed 
relationship could have been established between Portugal and the EU in the telecommunications sector.

Table 1: Participation of European Countries in RACE

\begin{tabular}{lll}
\hline Country & Participation & Pr \\
United Kingdom & 148 & 23 \\
Germany & 146 & 27 \\
France & 144 & 10 \\
Italy & 60 & 7 \\
Spain & 57 & 1 \\
Netherlands & 49 & 5 \\
Sweden & 39 & 2 \\
Belgium & 37 & 7 \\
Greece & 35 & 1 \\
Denmark & 34 & 2 \\
Ireland & 23 & 3 \\
Portugal & 23 & 2 \\
Finland & 17 & 1 \\
Norway & 14 & - \\
Switzerland & 12 & 1 \\
Austria & 4 & - \\
Total & 842 & 92
\end{tabular}

Source: Schröring, T 'European Telecommunications R\&D Systems in Transition' in Steinfield, Charles et al (eds) Telecommunications in Transition Sage, Thousand Oaks (1994)

Table 2: Participation of Organisations and Companies in RACE

\begin{tabular}{|lll}
\hline Companies & Participation & Pro \\
Alcatel & 70 & 15 \\
Philips & 30 & 4 \\
British Telecom & 29 & 6 \\
SwedischTelecom & 25 & 1 \\
Thomson & 23 & 3 \\
Telefonica & 21 & - \\
Netherlands PTT & 20 & - \\
France Télécom & 20 & - \\
Ericsson & 19 & 3 \\
DBP Telekom & 17 & 4 \\
Bosh Telecom & 15 & 1 \\
GEC & 15 & - \\
Siemens & 14 & 1 \\
STC & 13 & 3
\end{tabular}




\begin{tabular}{|lll} 
Plessey & 11 & 3 \\
Telecom Eireann & 10 & 3 \\
Kjobenhavns Telefon & 10 & - \\
AT\&T-NSI & 10 & - \\
IBM & 10 & 1 \\
Mafra & 10 & 1
\end{tabular}

Source: Schröring, op cit (table 1)

Table 3: Portuguese Projects Financed by STAR

\begin{tabular}{|ll}
\hline Type of Operation & Numb \\
Infrastructures & \\
ISDN & 36 \\
Mobile Telephone & 7 \\
Paging & 5 \\
Videoconference & 5 \\
Videotex & 5 \\
Text/Message Service (MHS/EDI) & 1 \\
Packet Switched Network/DACS and demand in & 8 \\
Incentives to offer and & \\
advanced services & \\
Studies & 8 \\
Demonstrations & 44 \\
Incentives & 1,148 \\
Creation of Regional Services & 2 \\
Total & 1,269
\end{tabular}

Source: adapted from Comissão Nacional do Programa STAR Portugal, Programa STAR, Relatório Final de Execução Comissão Nacional do Programa STAR, Lisbon (April 1993) 